Original Research Article

\title{
Cheura (Diploknema butyracea) as a livelihood option for forest-dweller tribe (Van-Raji) of Pithoragarh, Uttarakhand, India
}

Joshi, Naveen Chandra; Chaudhary, Alka and Rawat, Gopal Singh

Wildlife Institute of India, Chandrabani, Dehradun, India

Corresponding Author: dr.naveenchandrajoshi@gmail.com

\section{A R T I C L E I N F O}

Received: 01 February 2018 | Accepted: 22 April 2018 | Published Online: 15 August 2018

DOI: $10.31786 / 09756272.18 .9 .1 .116$

EOI: $10.11208 /$ essence.18.9.1.116

Article is an Open Access Publication.

This work is licensed under Attribution-Non Commercial 4.0 International

(https://creativecommons.org/licenses/by/4.0/)

CThe Authors (2018). Publishing Rights @ MANU-ICMANU \& ESSENCE-IJERC.

\section{A B S T R A C T}

This study documents the traditional uses of Cheura or Chyur (Diploknema butyracea) by a tribal group (Van-Raji) in Eastern Uttarakhand part of western Himalayan region. Cheura is one of the economically important but lesser known and underutilized multipurpose tree of Himalaya. It has a great spiritual and cultural importance along with livelihood association along the Himalayan communities especially the Van-Rajis, which are among the most ancient primitive vulnerable tribes (PVTs) of India with a population of around 700 in Uttarakhand. Field surveys were conducted during 2015-2017 to collect data on the availability and uses of various parts of this tree by the tribals in their 9 hamlets in Pithoragarh district of Uttarakhand. These tribals use almost all the parts of the tree and has a great economic value in respect of food, fuel wood, timber, fodder and other products. It is also used to cure many diseases and body disorders by the community people such as in inflammation of tonsils, rheumatism, itching, ulcers, hemorrhage, etc. All such uses are discussed. An attempt has also been made to document the current causes of habitat loss of this socio-economic important tree and traditional knowledge thereof along with a suggested action plan.

\section{K E Y W O R D S}

Himalaya | Livelihood | Tribal | Traditional knowledge | Habitat loss | Action plan

\section{I T A T I O N}

Joshi, Naveen Chandra; Chaudhary, Alka and Rawat, Gopal Singh (2018): Cheura (Diploknema butyracea) as a livelihood option for forest-dweller tribe (Van-Raji) of Pithoragarh, Uttarakhand, India. ESSENCE Int. J. Env. Rehab. Conserv. IX (1): 134-141. 


\section{Introduction}

Himalayan region which occupies only 15 percent of the country's geographical area, accounts for about 30 percent of the endemic species found in the Indian sub-continent [1]. Due to wide altitudinal range Himalaya has always been the best source of medicinal plants and most of the medicinal plants used in Indian traditional system of medicine are found in Himalaya. According to an estimate among the 1600 species of medicinal plants used in India [2], more than $50 \%$ species come from the Himalayan region [3]. The state of Uttarakhand which is situated in western Himalaya, is bestowed with a rich array of forest resources, especially medicinal and aromatic plants and this region holds most medicinal plants in comparison to other parts of India [4]. Many plants and trees have a wide range of uses. This kind of flora are economically and socio-cultural important for the local people and such trees are known as "Kalpavriksha" in ancient literature. According to Hindu mythology and the Vedic scriptures "Kalpavriksha" is a divine tree which fulfills all the wishes. In new era many trees which are

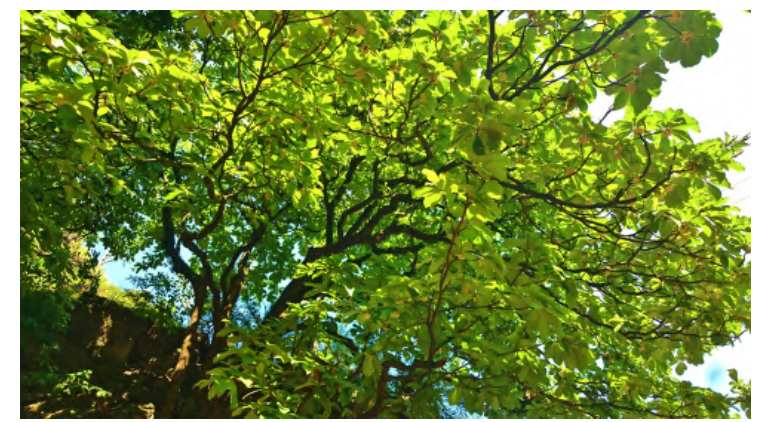

very useful and almost all the parts are useful are quoted as "Kalpvriksha" such as Cheura (Diploknema butyracea), Shami (Prosopis cineraria), Parijata (Erythrina variegata), Bargad (Ficus benghalensis), coconut (Cocos nucifera), Mahua (Madhuca longifolia), and mulberry (Morus nigra).

Among these Cheura (Diploknema butyracea) is the only native to Himalaya. It has medicinal and economic importance to various ethnic communities in western Himalaya with many uses of its different parts. It is a rich source of many useful substances like oil (edible and non- edible), honey, gur (jaggery), fodder for animals, hard and durable timber, medicines and pesticides apart from its role in soil and water conservation.

Besides being such an important tree it is facing a great habitat loss in the study area due to many factors including eroding traditional knowledge. We attempt to document the various uses of this tree as done by the local communities of the study area along with the identification of various reasons for its habitat loss in the study area.

\section{Material and Methodology}

The current study was carried out in all the nine hamlets of Van-Rajis and surrounding communities in Dharchula, Didihat and Kanalichina blocks of Pithoragarh district in Uttarakhand state of India. Van-Raji is an ethnic minority tribe of western Himalaya and known to be the descendants of Kirats. They were forest dwellers and hunter and gatherers living in caves till few decades back and now they reside in permanent settlements (9 hamlets) in Dharchula, Kanalichina and Didhat blocks of Pithoragarh district and one in Champawat district of Uttarakhand state. They are rich of traditional ecological knowledge especially pertaining to wild flora and fauna which has helped them through generations to sustain in deep forests (Fig. 1).

\section{Distribution of Cheura tree}

The Indian butter tree (Diploknema butyracea) also known by synonyms Bassia butyracea (Roxb.); Madhuca butyracea (Roxb.) Macbride; Illipe butyracea (Roxb.) Engl.; Aesandra butyracea (Roxb.) Baehni; Vidoricum butyraceum (Roxb.) Kuntze and Mixandra butyracea (Roxb.) Pierre ex L. Planch, is a deciduous tree about 15 -20 m high and is commonly known as Chyur or Cheura, Phulwara (Phalwara), Phulwaor Phulel in Northern parts of India, Chyuri in Nepal, Yika Shing in Bhutan and Gophal in Bengal. Distributed naturally throughout the forest of lower Himalaya between an altitude ranges of $300-1500 \mathrm{~m} 1$. Tree attains a height of $15 \mathrm{~m}$ and girth $1.8 \mathrm{~m}$, fruits are berries, 1-3 seeded and contain about $2.0 \mathrm{~cm}$ long almond shaped kernel. 


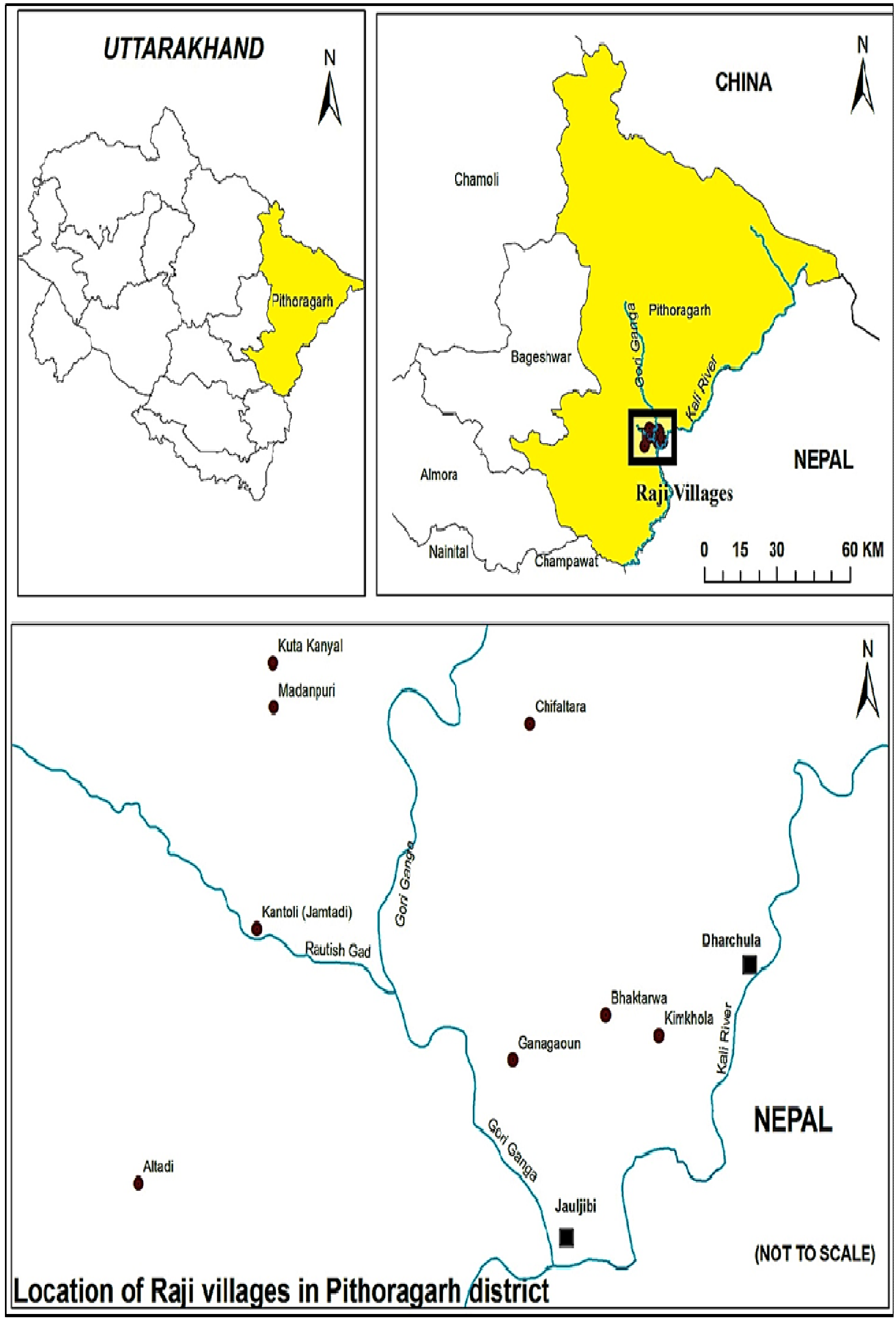

Fig. 1: Location of Raji settlements in Pithoragarh district of Uttarakhand. 
Cheura is native to the sub-Himalayan tracts of India, China, Nepal and Bhutan (Brandis 1906) and has been reported by almost whole range of Himalaya and grows mainly in the subHimalayan tracts on steep slopes, narrow shady valleys or gorges and cliffs at an altitude ranging from 300 to 1500 meters [5] [6]. The population of this species in Uttarakhand is almost localized in Pithoragarh district particularly the areas bordering Nepal and adjoining areas of Almora, Bageshwar and Champawat [7]. Thus the current study was made in Pithoragarh district of Uttarakhand state of India situated in Western Indian Himalaya Region (IHR).

\section{Field survey and data collection}

Field visits were carried out in different phases from October 2015- December 2017. Prior informed verbal consent was taken before data collection by explain the aim of the study to the respondents. Data was collected from primary sources through interactions, interviews and focus group discussions with value chain actors, and through secondary sources (review of past reports). A total of 108 respondents were interviewed and 8 group discussions were conducted. Rapid rural appraisal (RRA) was used to gather, confirm, and validate ethnobotanical information. An attempt was also made to document the efforts needed for the conservation of this medicinally and economic important tree along with the view of local community towards the habitat loss of this important tree.

The questions were based on the uses of various parts of the tree. A reconnaissance survey was carried out first in the local markets nearby to the patches of the Indian butter tree in order to know about the use value of Cheura in the local communities. On the basis of this survey a detailed survey was carried out in the local villages.

\section{Result}

Uses

The Cheura tree is used in many ways by the local community people in the study area. This is a tree of whose almost all the parts are used for some purpose. The main product of this tree
(Ghee or butter) is extracted from the seeds which is known as Cheura ghee or butter. It produces oil seeds, rich in oil contents which at lower temperature transforms into fat and looks like butter or ghee which has a great nutritional and medicinal value. Some of the main uses of the tree as done by the study community are as follows:

Seeds

Seeds which are brown in color are the most important part of this tree, as the seeds are used to extract fatty acid oil locally known as "Cheura ghee" which is a dense white colored substance used as vegetable oil as well as for lightening the lamps. The yield of vegetable oil is $42-47 \%$ of the weight of seeds [8]. The processing was earlier done at community level but now is undertaken at the individual household level. The oil thus obtained is also used for making chocolate, soap and candles. This oil is also used by the surrounding communities to cure many diseases and is considered good for many body disorders such as to relieve headache, rheumatic pains, ulcers, itching, hemorrhage, inflammation of tonsils etc. It is also applied on chapped hands and feet in winter. The oilcakes made out of the residual byproduct left after the extraction of Ghee and is equally important, as these are used as manure having pesticide properties and also as fish poison used in fishing as fishing has become one of their major source of income now. The residual substance is used as leech repellent and the local people rub its paste on their legs in the rainy season to repel the leech. As these oilcakes are considered toxic, these are not used as mulch for animals after detoxification. Fruit

Fruits are the other most important part of this tree. The fruit is berry, oval in shape with three seeds. The pericarp contains thick and soft pulp, which is sweet in taste and being used for making gur (jaggary) by crushing it and drying by boiling in conventional method. The gur is reported tasty and sold in local market at remunerative prices. The residuals are used as animal feed by mixing it with fodder. The fruit pulp is also edible and 
widely eaten by the native villagers and also by many birds, flies and wild animals. The pulp juice is considered to keep the body warm and it is generally prohibited during diarrhea, coughing and stomach-ache.

Leafs

The Leaves of Cheura are thinly coriaceous, obovate, alternate and usually clustered at apex of branchlets. The green leaves of Cheura are available during the dry months of the year and are thus preferred by the cattles to feed on. These

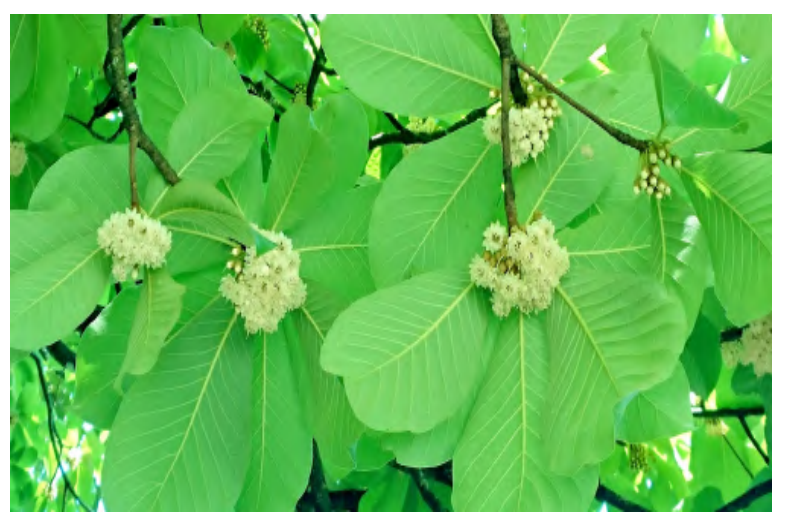

leaves are even traditionally considered good for lactating cattles. Besides being a good source of fodder for animals the leaves of Cheura are also used for making Dona or Thali (a plate made up of leafs for food) in various rituals and customs in Hindu culture by the natives of Uttarakhand. The plates thus prepared are considered sacred and are also used as plates for devoting edibles and other materials to the deities. The wild animals like macaque species and langurs also love to feed on the leaves of this tree.

Flowers

The flowering in it occurs from October Noveber onwards and it fruits in July-August. The inflorescence of Cheura are colored and rich in sugar which are traditionally considered good for foraging of various pollinators including bees, birds and bats. The honey produced by the honeybees after foraging on Cheura flowers is sold as Cheura honey by the natives at good cost thus being a good source of income. The nectar from the flowers is also harvested directly to produce a jaggery which is highly prized in Uttarakhand [9]. The nectar obtained by Cheura flowers is considered of great medicinal as well as nutri- tional use especially during famine. The Cheura honey is used in treatment of Diabetes and Asthma. The flowers are also used as a source of alcohol. The flowering in it occurs from OctoberNovember onwards and it fruits in July-August.

The inflorescence of Cheura are colored and rich in sugar which are traditionally considered good for foraging of various pollinators including bees, birds and bats. The honey produced by the honeybees after foraging on Cheura flowers is sold as Cheura honey by the natives at good cost thus being a good source of income. The nectar from the flowers is also harvested directly to produce a jaggery which is highly prized in Uttarakhand [9]. The nectar obtained by Cheura flowers is considered of great medicinal as well as nutritional use especially during famine. The Cheura honey is used in treatment of Diabetes and Asthma. The flowers are also used as a source of alcohol.

\section{Roots}

The roots are used as a tonic. The roots are cleaned and messed and dipped in water and kept for whole night or day and thereafter the juice thus prepared is taken as a tonic.

\section{Bark}

According to the elders of the community the bark of Cheura was widely used in dyeing (is rich in tannin) in earlier days but this practice has been discontinued now due to availability of many other synthetic dyes available in the market.

Wood

The Cheura tree may be $20-30 \mathrm{~m}$ in height. Stems are used for fulfilling the demands of wood as fuel and timber. The branches are used for fuel wood whereas, the trunk is used for timber. The wood of Cheura is considered best for fuelwood as it contains resins which does not allow it to extinguish fast and even gives less smoke on burning as compared to other fuelwoods. Although the wood of this tree is not considered very hard and durable still is used for making furniture and other items. The use of wood for making storage bins have also been reported [10]. 
Resin

The resin of the tree is used as an ointment for healing cuts and wounds by some tribal people like Van-Rajis in Dharchula block of Pithoragarh.

\section{Causes of Habitat Loss}

On the basis of the reconnaissance survey and field observations we can conclude that there are various threats which are responsible for the decline in the distribution and abundance of the Cheura tree among which the major threats are mentioned in following points.

\section{Degradation of traditional knowledge}

The production of Cheura ghee was so popular in earlier days that it was processed at a community level but now due to degradation of traditional knowledge it is undertaken at the individual household level consequently causing lack in the general awareness about the tree and low efforts for conservation and preservation of this species.

\section{Lack of conservation efforts}

Lack of efforts for conservation and preservation of this species by the policy makers and implementers is also one major factor behind the low habitat area of this species.

\section{High extraction rate}

Having such a great economic and medicinal value, Cheura is facing threat as the exploitation levels have reached all-time high, because of relentless anthropogenic pressure [11].

\section{Anthropogenic activities}

As the distribution of this species in western Himalaya is limited to Pithoragarh district particularly the areas bordering Nepal and adjoining areas of Almora, Bageshwar and Champawat, the rapid developmental process in this area including construction of roads and dams are also major threats to this plant species. As for example the largest proposed hydropower project in South Asia, the 6720 MW bi-national Pancheshwar project to be jointly constructed by India and Nepal on Mahakali river (the border between these two countries) and the total submergence area is 11,600 ha (India - 7,600 ha and Nepal - 4,000 ha.) is going to completely destruct the current and potential habitats of the species in western Himalaya. This dam is going to affect three districts of
Uttarakhand (Champawat, Pithoragarh and Almora) in India and three districts (Darchula, Baitadi and Dadeldhura) of Nepal bordering India. Thus an urgent attention is required to save the habitat of this species so that habitat loss could be minimized. Along with it identification of potential areas for habitat restoration also become important so that plantation programs for this species could be carried out in these areas and this species could be conserved in western Himalaya.

\section{Challenges And Opportunities}

The latex yielding plant such as D. butyracea suits to different edaphic climatic conditions and thus does not compete with the traditional crops [12]. These can be grown in degraded or infertile lands since these are hard, tolerant species that can face the climactic up and downs of local hill ecology. Forests have the potential to improve the livelihood of forest dwelling people, particularly tribal people, who are among the most disadvantaged group in Indian society [7] and this species can be used as a tool to strengthen the economic condition of the deprived communities by utilizing their traditional knowledge for their empowerment. The potential use of Cheura products in different fields such as pharmaceuticals, vegetable ghee production, confectionary, soap making and candle manufacturing provides an opportunity to generate employment and a way forward to sustainable development.

\section{Suggestive action plan}

i. All the existing pockets of Cheura grown localities and traditional uses in local communities are required to be identified, documented, mapped and promoted.

ii. Detailed analysis of the habitat distribution and immediate threats to the habitat of the Cheura tree are to be identified in the study area and suitable agro-climatic locations should be identified throughout the Himalayan sub-tropical region so that this tree could be conserved in its natural habitat.

iii. Proper in-situ and ex-situ conservation strategies and propagation techniques such as tissue culture are urgently needed and nurseries 
should be set-up at best suitable habitats throughout the Himalayan region.

iii. After identification of suitable habitats for this tree the promotion of Cheura plantation and its application may be done in waste lands/panchayat lands in the rural areas by involving the State Forest Departments and local communities throughout the Himalayan region and in Andaman and Nicobar Islands.

iv. The plantation of Cheura may be included in the working plan of the State Forest Departments of Himalayan states. The plantation can also be promoted under the Agro-forestry schemes.

v. NGOs should be promoted to work for the conservation and preservation of this important tree and also for new plantation and use of produce of Cheura.

vi. The habitat of this tree should be included in the EIA plan of the proposed Pancheshwar Hydropower Project and adequate plantation should be done before damaging the natural habitat of the tree in the study area.

\section{Conclusion}

The potential use of Cheura products is found in different fields such as confectionary, vegetable ghee production, candle manufacturing, pharmaceuticals, and soap making.

Traditional knowledge can play an important role in sustainable development and climate change adaptation strategy. Recent global challenges such as food security, land degradation, genetic diversity loss and rapid climate change makes it necessary to focus on plantation of plant species having importance for other functions other than timber yield. Indigenous people have vast traditional knowledge about the uses of various plant resources and they have been following the practices for adaptation since time immortal. The programmes involving indigenous species and communities have become important in the last decades [13]. However, species selection still remained as ignored aspect in these programmes due to limited information on indigenous species [14]. In this condition species which are lesserknown, economically important and underutilized trees like D. butyracea, thus, become very important and must be included in the afforestation programs in Himalayan region as it can be grown in the ravines of hills. The tree suits to different edapho-climatic conditions and thus does not compete with the traditional crops. Plantation of 250 Cheura trees ha-1 can yield about 3.0-9.5 tons of green fodder after 14-16 years whereas, the annual income from oil and other by-products was estimated above Rupees One Lakh per ha-1year-1 which can be helpful for the economic uplifting of the village community [15] and farmers. While conducting Environment Impact Analysis (EIA) for developmental projects such species should be restored before clearance and plantation should be included in action plan of state Forest Departments in Himalayan region.

\section{Acknowledgment}

The authors are grateful to the Department of Science \& Technology (DST), Govt. of India for funding the research project on Traditional knowledge system in Himalaya and to the School of Environmental Sciences, Jawaharlal Nehru University, New Delhi for providing an opportunity to work as a collaborative partner of Task Force-5 under NMSHE project. We are also thankful to the local communities of the study area for their help, support and cooperation during the study.

\section{References}

Nautiyal, S.; Maikhuri, R. K.; Semwal, R. and Rao, K. (1998): "Conservation Through Cultivation: A Case Study of Medicinal Plants in Buffer Zone Villages of NDBR," in Research for Mountain Development: Some Initiatives and Accomplishments, Nainital, Gyanodaya Prakashan, 357.

Uniyal, S.; Awasthi, A. and Rawat, G. S.(2002): "Current status and distribution of commercially exploited medicinal and aromatic plants in upper Gori valley, Kumaun Himalaya, Uttaranchal," Curr. Sci., 82(10):1246-1252.

Adhikari, B.; Babu, M.; Saklani, P. and Rawat, G. S. (2003): "Medicinal tree of Uttaranchal State: Distribution, use pattern and prospects for conservation," Indian Forester, 129(2):243 
$-267$.

Dhyania, A.; Nautiyal, B. and Nautiyal, M. "Importance of Astavarga plants in traditional systems of medicine in Garhwal, Indian Himalaya," International Journal of Biodiversity Science, Ecosystem Services \& Management, 6(1-2):13-19.

Majumder, K.; Datta, B. and Shanlar, U. (2012): "Establishing continuity in distribution of Diploknema butyracea (Roxb.) H. J. Lam in Indian subcontinent," Journal of Research in Biology, 2(7):660-666.

Kunwar, A. and Thakur, A. (2017): "In-vitro callus regeneration and rhizogenesis in Diploknema butyracea: a valuable tree borne oilseed," Indian Journal of Research in Pharmacy and Biotechnology, 5(3):239-241.

Zargar, A. R. (2015): "Studies on variability and macropropagation in Diploknema butyracea Lam.," Forest Research Institute, Dehradun, PhD.

Khanka, M.; Tewari, L.; Kumar, S.; Singh, L. and Nailwal, T. K. (2010): "Extraction Of High Quality Dna From Diploknema Butyracea," Researcher, 2(9):19-20.

Bahar, N. (2011): "Cheura [Diploknema butyracea (Roxb.) H. J. Lam.]: an important tree for poverty alleviation," Indian Forester, 137 (11):1344-1345.

Mehta, P.; Negi, K.; Rathi, R. and Ojha, S. (2012): "Indigenous methods of seed conservation and protection in Uttarakhand Himalaya," Indian Journal of Traditional Knowledge, 11(2): 279-282.

Biswas, S.; Jain, S. and Pal, M. (2003): "Research needs and priorities for conservation of Indian Medicinal flora," Indian Forester, 129(1):8692.

Khanka, M.; Tewari, L.; Kumar, S.; Singh, L. and Nailwal, T. K. (2010): "Extraction of high quality DNA from Diploknema butyracea," Researcher, 2(9):19-20.

Leakey, R.; Tchoundjeu, Z.; Schreckenberg, K.; Shackleton, S. and Shackleton, C. (2005): "Agroforestry tree products (AFTPs): Targeting poverty reduction and enhanced liveli- hoods," Int. J. Agric. Sustain, 3:1-23.

Bhatt, V.; Purohit, V. and Negi, V. ( 2010): "Multipurpose tree species of Western Hiamalaya with an agroforestry prospective for rural needs," Journal of American Science, 6(1):7380.

Tewari, A.; Tamta, K. K.; Singh, N. and Mittal, A. (2016): "Cheura (Diploknema butyracea roxb.) a promising agroforestry tree species between $300-1500 \mathrm{~m}$ elevation in Kumaun region of Uttarakhand," in Uttarakhand paripeksya me krishi vaniki padhyatiyo ka abhilekhikaran evam sanstutiyan. 